\title{
Food practice for physical and spiritual well-being of the Zeme, the tribe in Northeast India
}

\author{
N. Atungbou(D)
}

\begin{abstract}
Food is a necessity for physical and spiritual well-being. It is sacred, identity, medicines, arts, religion, politics, social and legal. The different social system is recognised by the type of food that people consumed demarcating self and others. For some, certain foods are delicacies but taboo for others. Nevertheless, taste and smell determine the delicacy of the food. Against this background, the paper examines the traditional concept of food, food practices, and different types of food that the Zeme consumes in brief. The paper explores the delicacies of dry season food such as nkampi chutney, fermentation of bamboo shoots, namely kechui-hia and kechui-nnang, and mustard leaf paste-taste making, njetim, and the local beverages called zou. The paper locates the different local beverages in the context of legal, social, religion and gender implications. The study observed that the Zeme's food practices have gone through radical changes with the appropriation of the other food practices engrossed into the realm of market enterprises. It is of the view that proper value addition to the food practices can enhance their livelihood opportunities. The paper concluded that it serves as a foundation for the scientific investigation on the Zeme's food practice in general and fermented food making in particular, and contributions to the food literature.
\end{abstract}

Keywords: Zeme food practice, Physical, Spiritual well-being, Northeast, njetim, nkampitam, kechuihia, kechui-nnang, zou

\section{Introduction}

Food is a necessity for the survival of every living creature. Humans survived by consuming plants, and animals that supply energy, protein and vitamin. It is a complex whole of sacred, ethics, politics, social, artistic and identity. Symbolically, food demarcates between 'self' and 'other' solidifying group membership in the social system [1]. Community is recognised and identified by the types of food that they consumed on a daily basis or on special occasions. Every social system determines what constitutes food and what is not, permissible and not permissible, and symbolic bounded by normative standards of the particular social system. Since ancient times, healthy food practices and appropriate diet

Correspondence: atungbou10@gmail.com

Department of Humanities and Social Sciences, Sikkim Manipal University, Gangtok 737102, India

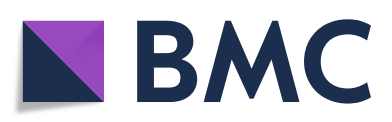

systems by avoiding excess in consumption have been in place [2]. Philosophers of the different era have discussed various aspects of food but the philosophical debate has been neglected, as it is considered too physical and momentary to deserve serious consideration [3]. Conventionally, food has been equated to women's work and unworthy topic [4], and too basic to be analysed philosophically [5]. However, contemporary philosophers considered the issues of technology, rights, and responsibilities of consumers and producers linking the metaphysical and epistemological concern [6].

Nevertheless, the genesis of the food studies emerged focusing on the symbolism and socio-cultural setting equating eating and dine with the barbarian and cultured ma $\mathrm{n}[7]$, religious practices and the feasts [8], and learning social organisation encoded inclusion and exclusion, boundaries and transactions [9-11]. Further studies

(c) The Author(s). 2020 Open Access This article is licensed under a Creative Commons Attribution 4.0 International License, which permits use, sharing, adaptation, distribution and reproduction in any medium or format, as long as you give

appropriate credit to the original author(s) and the source, provide a link to the Creative Commons licence, and indicate if changes were made. The images or other third party material in this article are included in the article's Creative Commons licence, unless indicated otherwise in a credit line to the material. If material is not included in the article's Creative Commons licence and your intended use is not permitted by statutory regulation or exceeds the permitted use, you will need to obtain permission directly from the copyright holder. To view a copy of this licence, visit http://creativecommons.org/licenses/by/4.0/. 
pointed out food rituals and taboo acted as devices for collective sentiments [12], and complex patterns of belief and social reciprocity [13] that provides the form of symbiosis [14]. And the aspect of raw, cook and rotten, and culinary triangle [15]. Deviating from the symbolical analysis of food, functional, structural and cultural approaches emerged [16]. The contemporary interest emerged with the emerging food technologies, markets, and identity [17], food-safety [18], insecurities and anxieties [19] and significantly ethical concerns [20, 21]. The sociological quest has been addressed through ethnographic methods by identifying localised social and relational norms, and values respond to the changes in the social context [22].

\section{About the study tribe}

The Zeme tribe is a patrilineal society found in the Indian states of Assam, Manipur, and Nagaland with a population of little less than a hundred thousand. Zeme is recognised as one of the Scheduled Tribes (ST) [23], belonging to the Mongoloid stock of IndoBurman group, linguistically to Naga-Bodo-Sub-Group of Tibeto-Burman language [24] and ethnically to a larger Naga family. The Zeme tribe share similar features with other ethnic groups in the Northeast India, and East and South-East Asian countries. It is argued that the Nagas immigrated in three directions viz; the North-East [25], the North-West [26] and the SouthEast [27]. Some had connected to the Head-hunters of Malay and the races of the Southern Seas (Myanmar) and traced back to China [28]. However, tradition and comparative physiology point to the North-Western China between the upper course of the Yangtze Kiang and the Hwang $\mathrm{Ho}$ as their original home [24]. It is also said that those people moved southward down the Brahmaputra valley were forced into the mountains and became the ancestors of the Naga s[29]. The Zeme might have migrated from different places and came to the place called Makhel (the present-day Manipur), and live together with other Naga tribes, then dispersed to different places and to present location (Fig. 1).

The Zeme tribe is gerontocratic and patriarchal in practice and authority, patrilocal in marriage and patrilineal in descent. Monogamy is the accepted form of marriage, but there was no rigid rule prohibiting polygamy in the pre-Christian era [30]. Predominantly, the Zeme tribe practice Christianity. In addition, they also have other religious practices such as Paupai-tenase (forefather's religion) and Heraka (syncretised religion). Adaptation of Christianity coupled with western education, the Zeme society witnessed radical changes in lifestyle and food practices.

\section{Framework of the paper}

The cultural landscape of India is littered with food [31], having a deep Epicurean interest, and symbolic that links between kith and kin, man and beast and god [32]. The different historical phase has shown regional food diversity from ancient to contemporary times [33]. Every region has particular flavours and techniques of food preparation where religion, custom and tradition influence and determine the food habits. Of these, beef avoidance had captured the attention of scholars, every now and then [34-36], prevalence of food ideologies and preference [37-39]. Few have attempted on the contemporary food habits [40] focusing on the socio-cultural changes [41]. A lacuna in the food literature is that, studied have not explored the village, caste, and the kinship linking food practices of food practices [42] to the socio-cultural reality $[43,44]$. In addition, the literature on the Indian food culture has not covered the regional diversity negating the marginal or subaltern food culture, in particular, the Naga food culture. Nevertheless, few colonial accounts provide information on the Naga food linking rituals and taboo s[45-47], and sex and age restriction on consumption of different food item $\mathrm{s}$ [48].

In academic discourse, deductive understanding of the Nagas and the Indian society with distinct entity vis-avis vegetarianism and the meatatarianism. Naga considered everything under the sun is consumable for the well-being of biological and physical strength. The Naga eat varieties of wild meats, vegetables, rice, chilies and gravies. Meat is one of their favourite food items. In addition, fermented and dry foodstuff is their favourite cuisine, sometimes create a lot of fuses. Culture of smell has been the dialectical issue within the Indian society that fixes Bourdieu's game of culture, nuances of how society defines and constructs one's identity through food [49]. Limited empirical knowledge patterning to the food practices has been one of the reasons, and the available pieces of literature have equated native food practices to superstitious, and failed to see the purposive and normative standard. Against this backdrop, the paper examines the Zeme's food practices, changes and revivalism. This paper contributes to the growing literature of food studies by locating the Zeme concept of food, types of food consumption, food taboo, vis-a-vis social and rituals and process of food preparation. Further, it examines the changes in food habits locating the influence of Christianity, and denominational prohibition, and food revivalism in the context of sociocultural transformations.

A study of this nature necessitates the collection of both primary and secondary data emphasising on the qualitative design. The thematic review has been made on secondary data to have a comprehensive understanding and to establish and to link the Zeme food practices 
with the academic world. Primary data is given emphasis in entailing the description of the phenomenon under study, the Zeme.

\section{Zeme concept of food}

According to the Zeme vernacular, food is called keteukesak, consisting of both cooked and raw, and solid and liquid. Etymologically speaking, keteu-kesak is a compounded term, 'keteu' mean eating and 'kesak', drinking. Food, according to the Zeme, is to be respected but not to be wasted. It is ethically bound to consume and finished without leaving the 'received food'. It is believed that a person whose plate is left with food items have no respect for the food and the one who provides. It is advised not to laugh at or make fun, stepping on the food items and if one does, the food would cry and disappear and he/she would eventually become poor. Treat food as a 'sacred thing.' Eating time is a sacred hour for the family where seats in the kitchen are arranged according to sex and age. By normal standard, every Zeme families used to cook plenty of food for every meal. Embraced by the idea of a healthy life and eating good food, the traditional festival also encourages good health practices as they believed that human beings need good rest and good physical features. So, food and health are intrinsically linked to every Zeme's individual life.

\section{Food practices}

Rice is the staple food. Generally, the Zeme have two meals a day. Food is taken at sunrise before going to the field or workplace and after returning from the field or from work just before the sunset. A mid-day meal is taken if they work for the whole day. The Zeme eat together during festive occasions as well as on ordinary days. The cooked food items are being shared at the community feast and between two individuals. One of the very common practices practiced is 'kuakpuangiteube' meaning 'feasting through sharing of food'. Etymologically speaking, kuak is plat, pua is to carry, $n g i$ is feast and festival and teube is eating. Different items are kept on the plate and go to a friend's place or community gathering. Normally, it carried out on a rotational basis among the different age groups. Meats and vegetables are consumed on a daily basis. Animal fat is used for cooking curry. Beef, pork and chicken are the most common non-vegetarian foods and supplemented

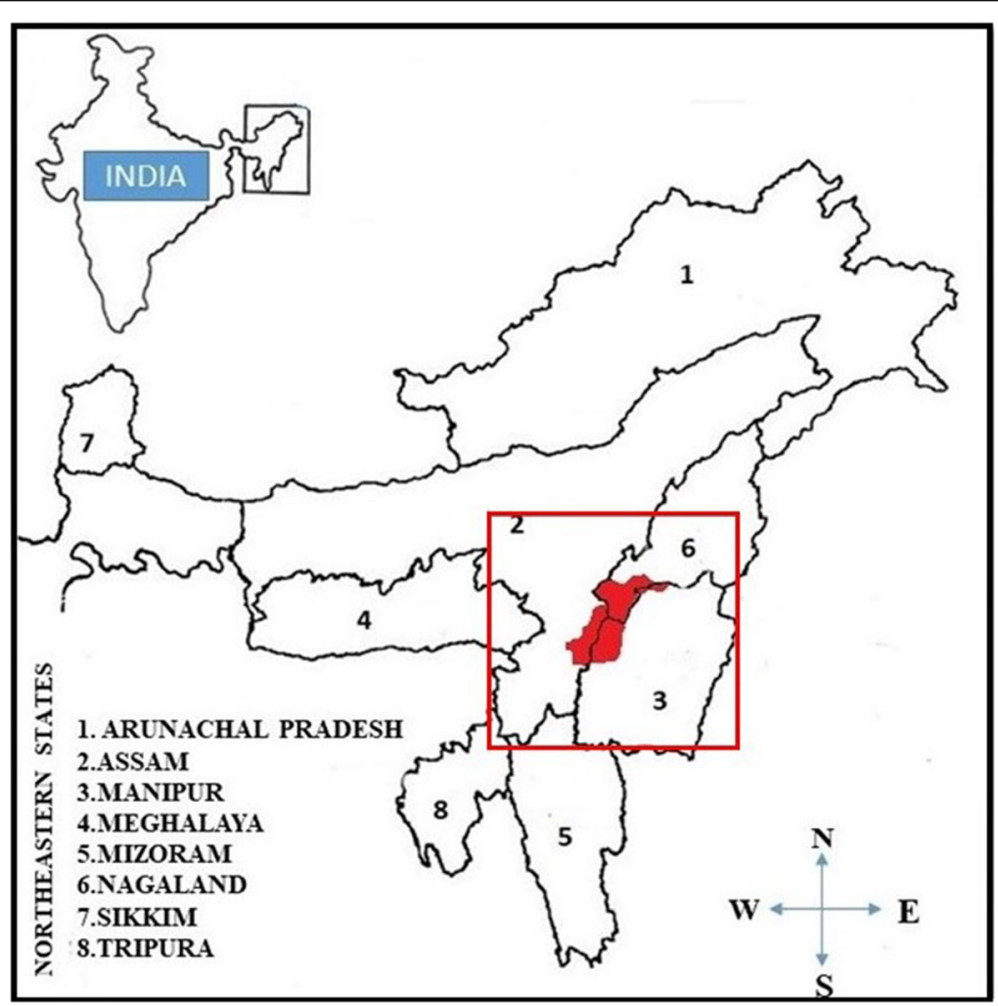

Fig. 1 Map showing Zeme inhabited areas as marked in Red. Map extracted from http://www.kiran.nic.in/NMSHE-2016.html, copy edited in locating the Zeme inhabited areas in Northeast India. The Zeme tribe can be located at latitude $25^{\circ} 29^{\prime} 59.99^{\prime \prime} \mathrm{N}$ and longitude $93^{\circ} 00^{\prime} 0.00^{\prime \prime} \mathrm{E}$ in Dimasa Hasao District, Assam, https://latitude.to/articles-by country/in/india/36984/dima-hasao-district; latitude $24^{\circ} 58^{\prime} 0.12^{\prime \prime} \mathrm{N}$ and longitude $93^{\circ}$ 32' 60.00" E in Tamenglong District, Manipur: https://latitude.to/articles-by-country/in/india/99514/tamenglong; latitude $25^{\circ} 27^{\prime} 59.99^{\prime \prime} \mathrm{N}$ and longitude $94^{\circ} 07^{\prime}$ 60.00" E in Senapati District, Manipur: https://latitude.to/articles-by-country/in/india/277402/tadubi; latitude $25^{\circ} 33^{\prime} 14.40^{\prime \prime} \mathrm{N}$ and longitude $93^{\circ} 44^{\prime}$ 26.16" E in Peren Distict, Nagaland: https://latitude.to/articles-by-country/in/india/196171/peren 
by mithun-gayal (semi-bison) and dog meats on some occasions. Pork is their favourite delicacy, and flesh of the mithun features during the festivals. The animal hide is one of the delicacies, prepared by way of burning and roasted then sliced into pieces and mixed with chilly. A large piece of meat and fish are smoked and dried and used as stored food. Fish, crab, prawn, snail and tortoise are delicious seafood.

\section{Njetim (mustard paste-taste maker)}

Njetim is made from the fermented mustard leaf. The process of making njetim (Fig. 2) is as follows: (i) green mustard leaves are washed with water and kept in the byliang (splint bamboo made tray-square in shape) for three to four days until it turns yellow; (ii) the yellowish leaves are pounded and soaked in the pot with a few cups of water for few days; and (iii) when it spreads the pungent smell, the juice is squeezed out. Then the juice is boiled by adding a small quantity of salt until it turns black and put in container. Njetim is ready to eat with any food item either with chilly or with rice. All parts of mustard leaves are used for curry and chutney either by drying or raw with some vegetables. From the making of njetim, other two items were also extracted. After taking out its juice and the remains is called njetak, and when it is dry, it is called njekang. Njetak is consumed as curry and chutney by adding raw vegetables while njekang is prepared with rice as curry. Njetim chutney with banana stems and garlic leaves are usually served during the hot season and also during leisure time. This kind of chutney is important because it can keep the body temperature down. In making these appetisers, chilly is added. Njetim can be preserved for long-it can go for many months. Njetim is also used in making fresh fruit chutney such as peach, mangos and other wild fruits during summer. Njetim is a versatile fermented food item that fixed in any items.

\section{Nkampitam (parkia bean chutney)}

Parkia is one of the most popular dry season food stuffs and one of the major income generated non-timber forest products. In Zeme, it is called nkampi. It is harvested in winter and ends up by the early spring. There are certain procedures that have to be followed in the making of nkampitam (Fig. 3). A mature bean is plugged from the tree, the peel is removed, sliced into small pieces and boiled. When it is cooked, the beans are mixed with chilli and dry fish or fermented local vegetable seeds. It

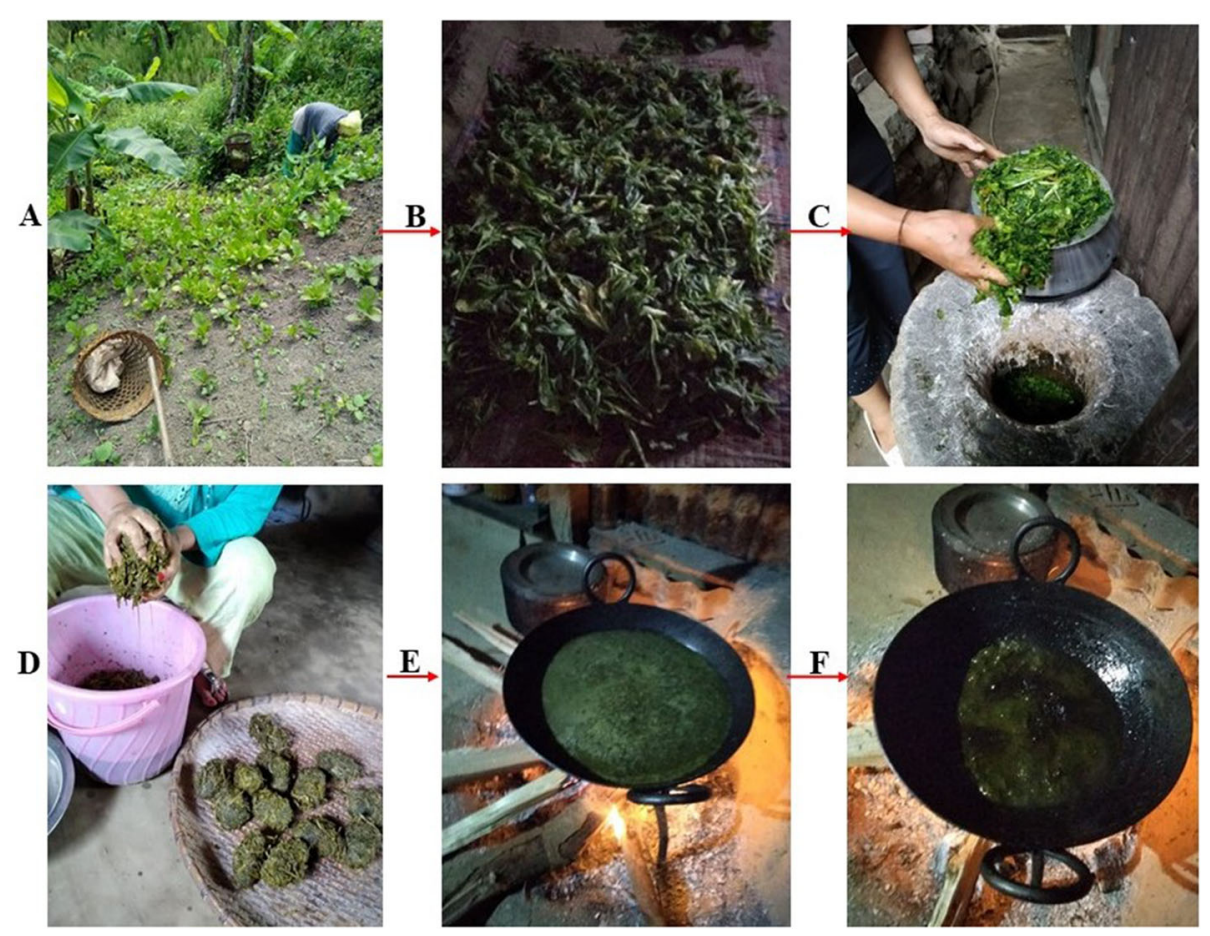

Fig. 2 Njetim is a popular fermented food stuff and ever-ready to consume; there are certain procedures to be followed in makings one. a Mature mustard leaves are collected from the field/farm, washed with water to make sure that there remains no dirt or mud. $\mathbf{b}$ The washed leaves are kept in byliang (traditional bamboo tray), in a selected room for a few days to enable the green leaves to turn yellow. $\mathbf{c}$ Yellowish leaves are pounded in traditional rice pounder called kepha, then pounded leaves are transferred to pots, added with some water and again kept for some days. $\mathbf{d}$ Once the pungent turn in a few days, its juice is squeezed out, and the remains called njetak used for curry or chutney can also dry, njetim. e Juice is boiled with salt before boiling; its juice is filtered in traditional filters made of bamboo. $\mathbf{f}$ Once the juice is cooked, it is transferred to a small pot and kept above the fire hearth called krab. Photo credit Majumthui Newme 


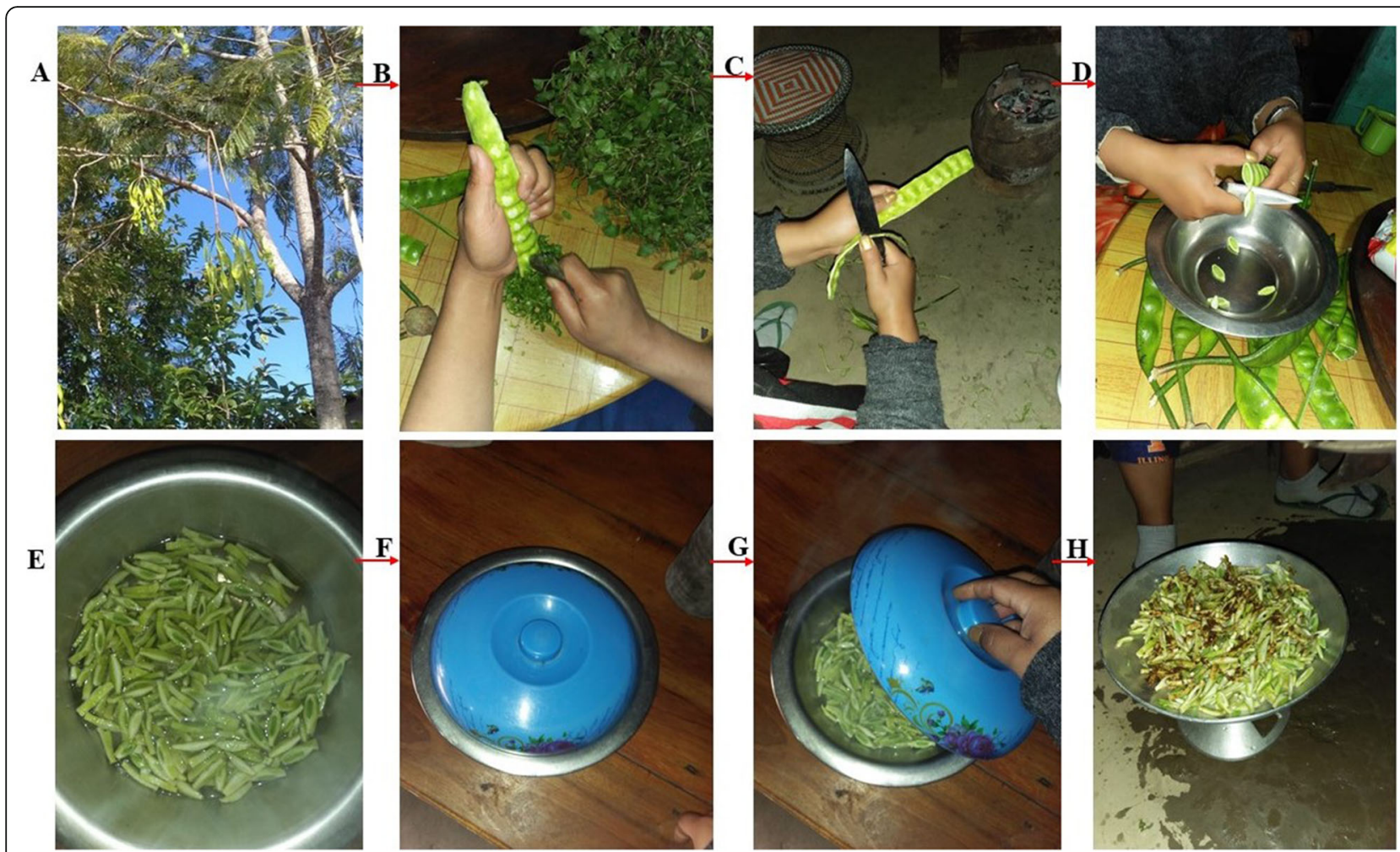

Fig. 3 Nkampitam is a popular dry season food item; in the making of this chutney, mature beans, chilli, salt, dry fish and fermented vegetables are used. a Bean gets mature in the month of December, and the month is appropriate for making chutney because of softness and tenderness. b Mature beans are plugged from the tree, and peel is removed by using indigenous made peeler. c After removing its peel, the harder sidelayer is removed by a kitchen knife. $\mathbf{d}$ Slice into small pieces. e The sliced pieces are transferred to the pot. $\mathbf{f}$ Then, add a small quantity of water, and cover and boil for about 10 min. $\mathbf{g}$ When it is boiled, pot cover is removed, and the boiled beans are transferred to the plate. $\mathbf{h}$ Chilli and dry fish or fermented vegetable seeds are pounded, and then beans are marinated. Photo credit Rosemary Newme

can also be made into salad with dry fish. Beans are eaten both as curry and chutney. Every part of parkia is not wasted and be used in the treatment of diarrhoea and dysentery too.

\section{Kechuihia (fermented bamboo shoot)}

Bamboo shoot is another popular important tropical food stuff. Young shoots are harvested in the month of June till September. The fermented shoots are stored in basket or pot and consumed throughout the year. Fermented bamboo shoots are used in vegetables and nonvegetables. Fermentation of bamboo shoots being carried out during June-August. However, there are different types of fermented bamboo shoots practiced by the Zeme. In this paper, only two types are described. The first one is called kechuihia (Fig. 4). For making kechuihia, in the month of June, fresh shoots are collected then removed sheaths, sliced into pieces, and put in a pot with little quantity of water. The shoots get fermented within 10 days, and its juice is filtered and stored in a separate containers. Fermented bamboo shoots are ready to be cooked in any curry.

\section{Zou (rice beverage)}

The local beverage is called Zou, used on multiple occasions such as ritual, case hearing, feast, festivals, marital negotiation and sickness. The Zeme believe that the local drink originated from leakage of sexual fluids of Tukpui and Tukpeu's intercourse which spread to the tree. From this tree, people discovered the secret of aromatic smell and began to use this tree's bark in making zou. There are different types of drinks and they are Tekuizou, Tamzou/Lingtakzou and Nduizou.

Tekuizou, also known as zousang, is made by soaking rice and paddy in water. Slowly, it germinates and young sprouts grow from soaked paddy in a few days. It is distilled and dried up. Both the rice and sprouted paddy are pounded together and are mixed and put into gourd pot or wooden pot and later hot water then followed with cold water and sealed for about 1 week. Generally, it takes 5 days for filtration and fermentation.

\section{Ntamzou/Lingtakzou (corn beverage)}

This is prepared from pounded maize powder. The maize is boiled and spread out in a bamboo tray, and yeast is spread over it. The sprout seeds are mixed with 


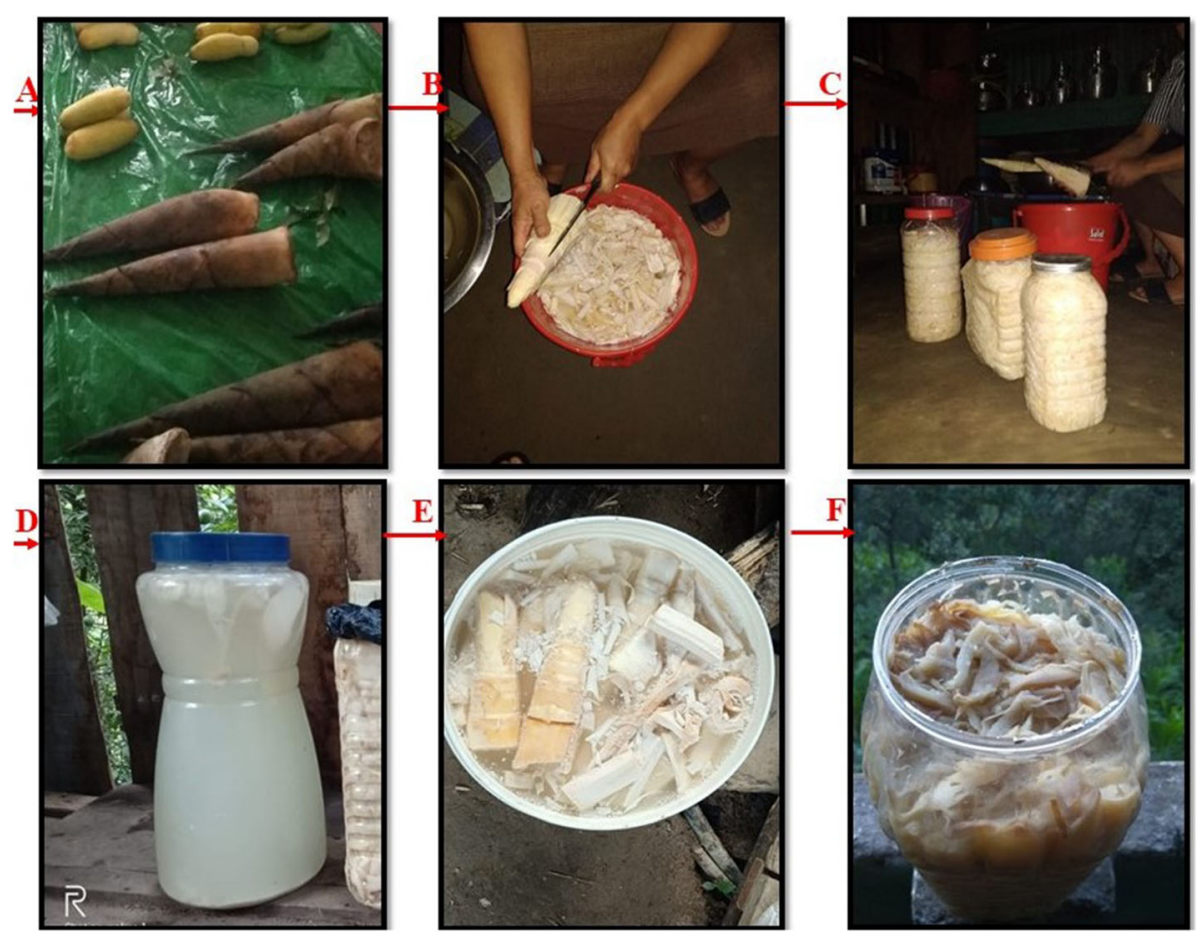

Fig. 4 Kechuihia is made from fresh tender bamboo shoots. a Tender bamboo shoots are collected from the forest, and sheaths are removed and washed with water. $\mathbf{b}$ The washed bamboo shoots are sliced into pieces. $\mathbf{c}$ The sliced bamboo shoots are transferred to containers, with little amount of water, containers are covered and kept for a week. $\mathbf{d}$ Once the bamboo shoots are fermented, juice is transferred to a different container. e After filtrations of juice from the fermented shoots, the shoots are transferred back to the container. $\mathbf{f}$ Fermented shoots are ready to use in vegetable and non-vegetables curryThe second type of fermented bamboo shoot is called kechui-nnang (Fig. 5). The collection of bamboo shoots for making kechui-nnang happens in the first week of August and ends in the first week of September. In the process, the grown shoots are collected with the help of hook or by chopping off from middle then remove sheaths, shoots are washed with water and cut into two equal sizes (vertical), and put in a conical bamboo basket lined with banana leaves. After the equal size of the shoots is put in the basket, the outer layer is covered with banana leaves and place two-three stones on top. Then, the bamboo basket is tied to the post. Fermentation of bamboo shoots may take 20 or more days. In the case of former (kechuihia), both juice and shoots are eaten while in the latter case, only shoots are taken but it can sustain throughout the year. Both types of fermented bamboo shoots are cooked with both vegetables and meats. Most importantly, preparing with pork is one of the most popular dishes among the Zeme.

the boiled maize and put into a basket and store it for a week for fermentation. The fermented mixture is then put into a bamboo tube (tepin) with water and the liquid is extracted by stirring. This type is used during festivals.

Nduizou (Fig. 6) is prepared in the same way as that of Tamzau. First, the rice is cooked and spread on a traditional tray, and when the rice is cold, nduihi (yeast) is mixed and wrapped in a basket with banana leaves. Two or three pieces of charcoal are kept on top of it to prevent harm. When the fermentation and filtration reach its climax, a liquid would drop off from the basket. It is called chiangne. Dripping off of the liquid indicates the maturity. It can be consumed with water or soaked in water and distilled from filter basket for two to three times in a similar procedure.

Consumption of Zou among the Zeme highlights the social structure. Tekuizou is common and suitable for everyone but tamzou/lingtakzou and nduizou are for elderly people. Chiangne (the first drip from nduizou) forbids children and women from consumption. It reveals the social values, institutionalised gender differences [50], political economy [51], basis of social allocation [52], right to food [53] and sexual identity [54-56]. Traditionally, tekuizou is offered to the guest as a sign of hospitality and respect. It is equivalent to offering a cup of tea or water. In any event, good or bad, varieties of drinks are used. For instance, if any individual injures fellow human beings over petty issues and the case is brought into the notice of the traditional court. In the legal context, to negotiate the case, the accused or defendant must place one pot of local drink, without which hearing of the case would not take place. In the marital negotiation context, negotiation or talk between the parents would not take place until the Nduizou pot is place before the girl's parent. It is not about the amount but the value of this drink.

In the religious context, Nduizou, also known as hera$z o u$, is used in every ritual whether to cease the evil 

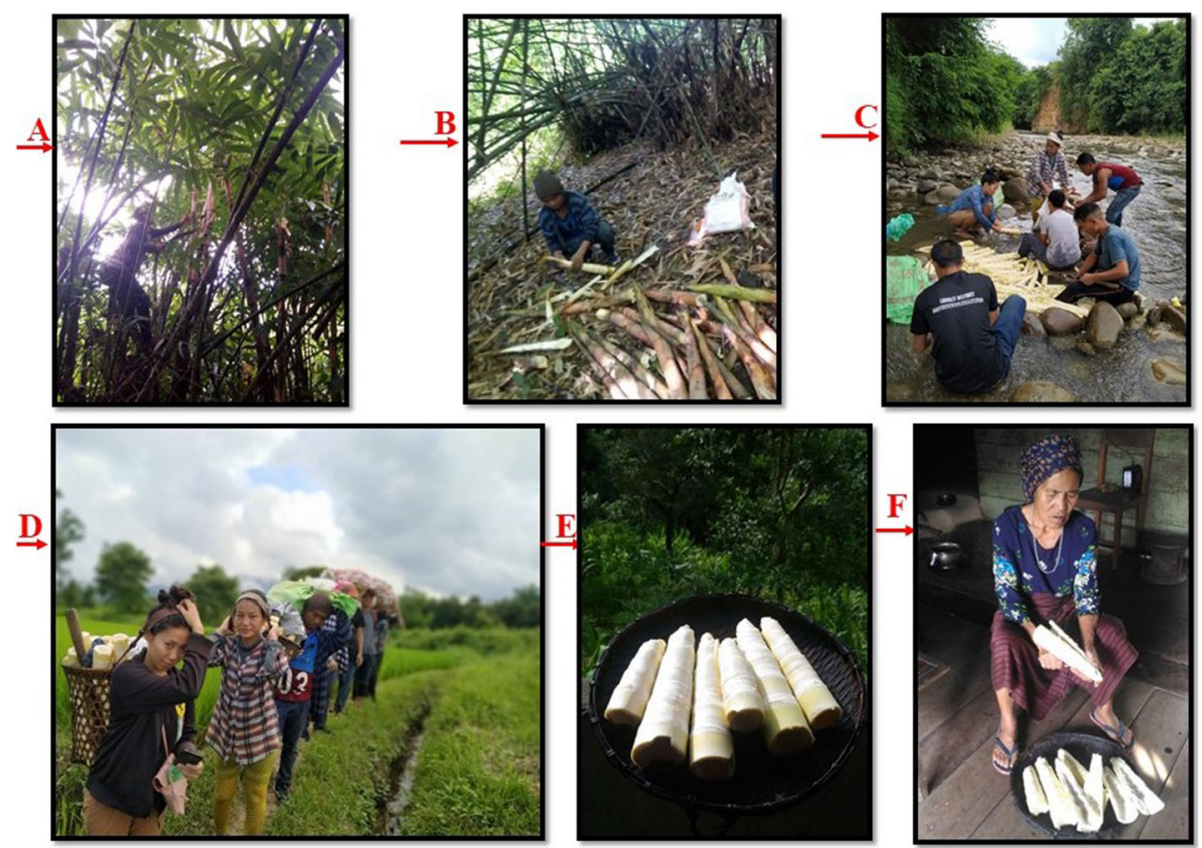

Fig. 5 Kechui-nnang is another type of bamboo shoots fermentation widely practiced by the Zeme tribe. a For this method of fermentation, grown tall bamboo shoots are collected; this bamboo shoot is in between becoming full bamboo but still the shoots are edible, the lower part is a grown bamboo but upper part is still remain shoots. $\mathbf{b}$ After cutting the tall shoots, the shoots are gathered in one place and the sheaths are removed. c Bamboo shoots are washed with water before taken to home. $\mathbf{d}$ Clean bamboo shoots is kept in traditional basket or shaken and taken to home. e Upon reaching home, clean bamboo shoots are unloaded and kept in traditional tray. f One by one, bamboo shoots are cut into equal size (vertical) and loaded in conical bamboo basket. Photo credit Heuchuneng and Catherine

spirits or thanking the almighty. Though this practice is not accustomed to one social system but universally found which connects humans with food to rituals, symbols and belief system s[8]. However, in the Christianoriented Zeme society, consumption of Zou is equated with immoral and having committed a sin. In reality, consumption of beverages is medically constructive and healthy for the person's physiological and psychological well-being. Constructive in this context symbolises the use of local drinks in good and bad times. Some studies have rightly pointed out that medical and sociological research exaggerates the problems of alcohol tending to be a western culture bias particularly entrenche $d[57]$. It is not to deviate from the harmful effect of alcohol consumption on human health but that has been addressed from the problem perspectives rather than purposive meaning. The Bible never said drink as a forbidden or unclean, advised to use for health and warns not to engage in immoral activities but filled with the spirit. The drink has to be used conscientiously for the well-being of the person. In consecrated contexts, food binds people together to their faiths [58], causal factors behind food taboo s[59], and also that transform taboo items into food [60]. In symbolic terms, it often serve either to reinforce or to question the hierarchical power relations or access to material goods [61].

\section{Discussion and conclusion}

The Zeme considered food is a necessity for physical and spiritual well-being. Food is sacred, a thing, social, legal, economy and most importantly identity. Food is to be respected but not to be wasted. Treat food as a sacred thing. Food hour is a sacred hour where seats are arranged according to sex and age. Food and health are intrinsically linked, embraced by the idea of a healthy life and eating good food, as the Zeme believed that human beings need good physical features. Food preparation and consumption are guided by socio-cultural practices. Nkampi chutney is one of the delicacies. The fermentation of various food items and food preparation is prepared as per their traditional knowledge system. Both veg and non-veg foods are prepared with fermented food items on a daily basis. Traditionally, zou is used in the context of social, sacred, political and legal which also has both biological. Tekuizou, also known as zousang, is taken by everyone and often offered to the guest instead of water or tea. In any event, good or bad, varieties of drinks are used. Children and women were forbidden 

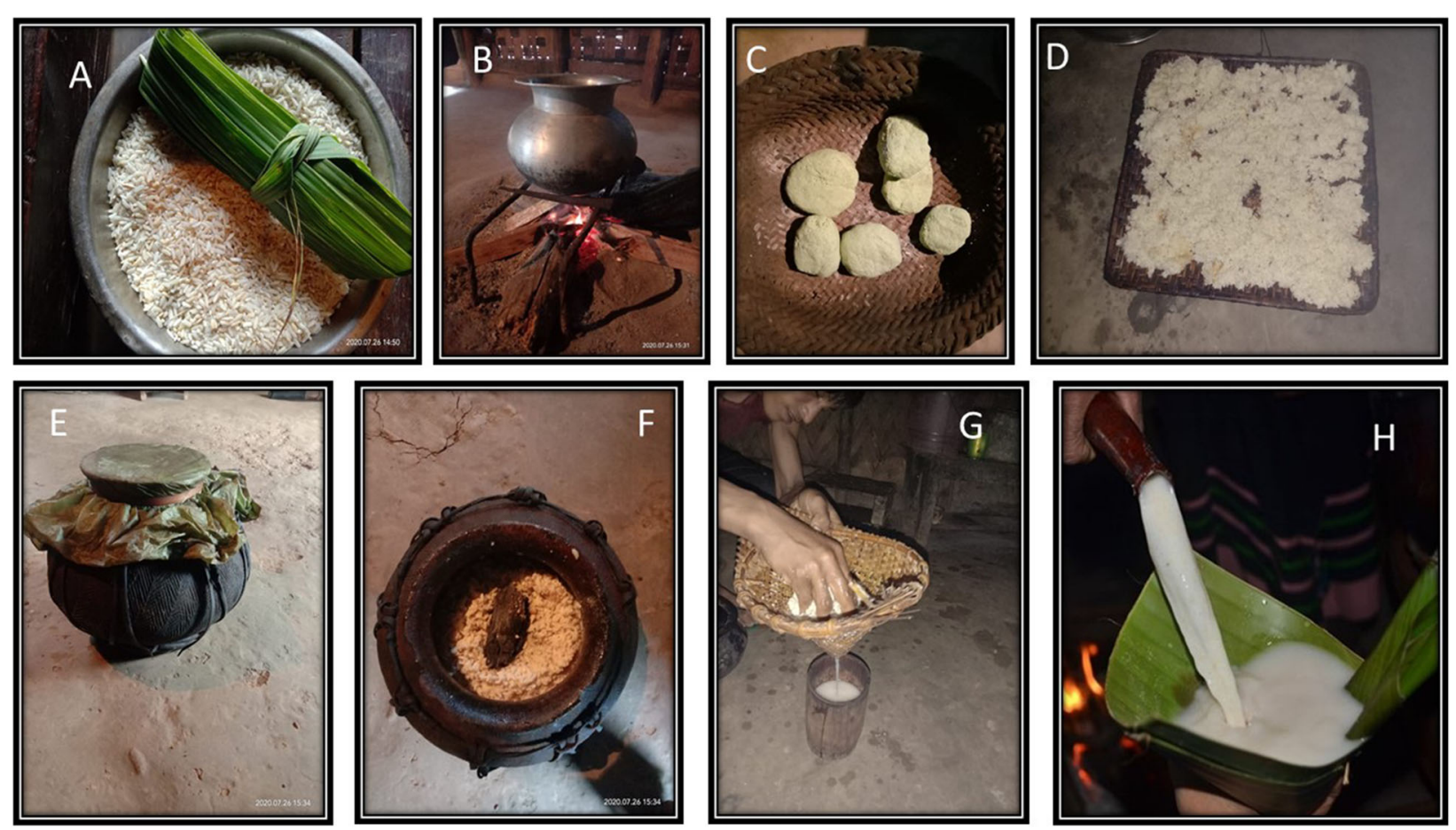

Fig. 6 Nduizou is an important drink, also known as herazou meaning sacred drink, use only in special occasion. a Rice and fresh sugarcane leaves are in place for making nduizou and yeast. b First step is to cook rice for making nduizou. $\mathbf{c}$ In the making of nduizou, yeast is added; yeast is made of sugarcane leaves and soaked rice. First, soaked rice is pounded, later sugarcane leaves are cut into small pieces and mixed with pounded soaked rice and pounded again. Once it is done, small quantity of water is added, squeezed with hand, made into cookies size and dried up. $\mathbf{d}$ Cooked rice is transferred to bamboo tray and kept for $1 \mathrm{~h}$, and then the yeast is mixed. e Mixed cooked rice and yeast is shifted to pot and covered with banana leaf. $\mathbf{f}$ Mature beer is ready to consume. $\mathbf{g}$ Rice beer is soaked in water and filtered in a traditional bamboo filter, Zou singrak. $\mathbf{h}$ Filtered rice beer is kept in gourd and put into the palm cup made of banana leaf. Photo credit Ewangbe, Simon and Atung

from consumption of the first drip from nduizou as they believe that this drink contains the sacred element. Nduizou is used in the settlement of disputes, legal matters and marital negotiation. Nevertheless, Zeme's food practices, methods and taste have gone through radical changes with the appropriation of other food practices. This appropriation engrossed in the commodification of njetim (mustard paste-taste maker), and kechuihia and kechui-nnang (fermented bamboo shoots) and sold in the open market where people are fetching a fair amount. It is observed that the proper value addition can enhance livelihood opportunities. In conclusion, the paper serves as a root for the scientific investigation on the food Zeme's practice in general and fermented foodmaking in particular, and contribution to the food literature.

\section{Acknowledgements}

The author wishes to thank respondents for their cooperation and for providing valuable information.

\section{Funding}

The author received no financial support for the research, authorship and/or publication of this article.

\section{Availability of data and materials} Not applicable

\section{Competing interests}

The author declares no competing interests.

Received: 4 March 2020 Accepted: 5 November 2020

Published online: 26 November 2020

\section{References}

1. Mintz SW, Du Bois CM. The Anthropology of Food and Eating. Annu Rev Anthropol. 2002;31:99-119. https://doi.org/10.1146/annurev.anthro.32. 032702.131011.

2. Skiadas PK, Lascaratos JG. Dietetics in ancient Greek philosophy: Plato's concepts of healthy diet. Eur J Clin Nutr. 2001;55(7):532-7. https://doi.org/ 10.1038/sj.ejcn.1601179.

3. Telfer E. Food for thought: Philosophy and Food. London: Routledge; 1996.

4. Curtin DW, Heldke LM. Cooking, eating, thinking: transformative philosophies of food. Bloomington: Indiana University Press; 1992

5. Korsmeyer C. Delightful, delicious, disgusting. J Aesthet Art Crit. 2002;60(3): 217-25. https://doi.org/10.1111/1540-6245.00069.

6. Kaplan DM. The Philosophy of food. In: Kaplan DM, editor. The philosophy of food. Berkeley: University California Press; 2012. p. 1-23.

7. Mallery G. Manners and Meals. Am Anthropol. 1888;1(3):193-208. https://doi. org/10.1525/aa.1888.1.3.02a00000. 
8. Smith WR. Lectures on the religion of the Semites. New York: Appleton; 1889.

9. Cushing FH. Zuñi breadstuff. New York: MAlH Foundation; 1974. https:// archive.org/details/zuibreadstuffoocush.

10. Boas F. Contributions to the ethnology of the Kwakiutl. New York: Columbia University Press; 1925. https://open.library.ubc.ca/collections/bcbooks/ items $/ 1.0376481$

11. Mennell S, Murcott A, Van Otterloo AH. The sociology of food: eating, diet, and culture. ISA: Sage Publications; 1992. https://doi.org/10.2307/2076009.

12. Radcliffe-Brown AR. The Andaman Islanders: a study in anthropology (Anthony Wilkin studentship research, 1906). Cambridge: Cambridge University Press; 1922. https://babel.hathitrust.org/cgi/pt?id=mdp.390150046 76279\&view=1 up\&seq $=27$.

13. Malinowski B. Coral Gardens and their magic: a study of the methods of tilling the soil and of agricultural rites in the Trobriand Islands. London: Routledge; 1935.

14. Evans-Pritchard EE. The Zande Trickster. Oxford: Clarendon Press; 1967.

15. Lévi-Strauss C. Le triangle culinaire (1965). Food Hist. 2004;2(1):7-20. https:// doi.org/10.1484/J.FOOD.2.300271.

16. Goody J, Goody JR. Cooking, Cuisine and Class: A Study in Comparative Sociology. Cambridge: Cambridge University Press; 1982.

17. Fischler C. Food, self and identity. Soc Sci Inf. 1988;27(2):275-92. https://doi. org/10.1177/053901888027002005.

18. Buchler S, Smith K, Lawrence G. Food risks, old and new: Demographic characteristics and perceptions of food additives, regulation and contamination in Australia. J Sociol. 2010;46(4):353-74. https://doi.org/10. 1177/1440783310384449.

19. Crawford RJM. Accounting for food requirements of seabirds in fisheries management - the case of the South African purse-seine fishery. Afr J Mar Sci. 2004;26(1):197-203. https://doi.org/10.2989/18142320409504057.

20. Soper K. Re-thinking the 'Good Life': the citizenship dimension of consumer disaffection with consumerism. J Consum Cult. 2007;2(4):205-29. https://doi. org/10.1177/1469540507077681.

21. DuPuis EM, Goodman D. Should we go "home" to eat?: toward a reflexive politics of localism. J Rural Stud. 2005;21(3):359-71. https://doi.org/10.1016/j. jrurstud.2005.05.011.

22. Isaacs B, Dixon J, Banwell C, et al. Competition, adaptation and mutation: fresh market and supermarket conventions in Thailand. J Sociol. 2010;46(4): 413-36. https://doi.org/10.1177/1440783310384454.

23. Ministry of Law and Justice. Constitution (Scheduled Tribe) order (amendment) bill, 2011. New Delhi: Government of India; 2012. https:// www.india.gov.in/constitution-scheduled-tribes-order-amendment-act-2011.

24. Grierson GA. Linguistic survey of India vol. 3 Tibeto-Burman family part 1 general introduction, specimens of the Tibetan dialects, the Himalayan dialects and North Assam group. Calcutta: Superintendent of Government Print; 1909.

25. Johnstone SJ. My Experiences in Manipur and the Naga Hills. London: SL Marston Co.; 1896

26. Horam M. Naga Polity. New Delhi: BR Publishing; 1975.

27. Elwin V. The Nagas in the nineteenth century. London: Oxford University Press; 1969

28. Hutton JH. The Angami Nagas: With Some Notes on Neighbouring Tribes. Oxford: Oxford University Press; 1969.

29. Smith WC. The Ao-Naga Tribes of Assam. London: Macmillan; 1925.

30. Atungbou N. Practice of taking ndeu (price of a woman) in the Zeme society. Int J Res Humanit Soc. 2016;3(5):21-7 https://www.ijrhss.org/v3-15.

31. Olivelle P. Food in India. J Indian Philos. 1995;23(3):367-80. https://doi.org/ 10.1007/BF01463136.

32. Madan TN. The Gift of food. In: Nair BN, editor. Culture and society: a festschrift to Dr. A. Aiyappan. New Delhi: Thomson Press; 1975. p. 84-96.

33. Achaya KT. Indian food: a historical companion. New Delhi: Oxford University Press; 1994.

34. Harris M. The Cultural ecology of India's sacred cattle. Curr Anthropol. 1992; 33(1):261-76. https://doi.org/10.1086/200662.

35. Diener P, Nonini D, Robkin EE. The dialectics of the sacred cow: ecological adaptation versus political appropriation in the origins of India's cattle complex. Dialect Anthropol. 1978;3(3):221-41. https://doi.org/10.1007/ BF00288480

36. Nair KN. Animal protein consumption and the sacred cow complex in India. In: Harris M, Ross EB, editors. Food and evolution: toward a theory of human food habits 1987. Philadelphia: Temple University Press; 1987. p. $445-54$.

37. Ferro-Luzzi GE. Food avoidances of Indian Tribes. Anthropos. 1975;70(3/4): 385-427 https://www.persee.fr/doc/jatba_0021-7662_1975_num_22_1 0_3222_t1_0372_0000_2.

38. Moskowitz HW, Kumaraiah V, Sharma KN, et al. Cross-cultural differences in simple taste preferences. Science. 1975;190(4220):1217-8. https://doi.org/10. 1126/science.1198109.

39. Pool R. Beliefs concerning the avoidance of food during pregnancy and the immediate post-partum period in a tribal area of Rural Gujarat. India. Eastern Anthropol. 1986;39(3):251-9 https://pascal-francis.inist.fr/vibad/index. php?action=getRecordDetail\&lang=en\&idt=11998587.

40. Sanyal TK. And keeping the flame alive: a study on food habits and dietaries with nutritional efficiency of West Bengal Tribes. Calcutta: Calcutta Research Institute; 1979.

41. Appadurai A. How to make a national cuisine: cookbooks in contemporary India. Comp Stud Soc Hist. 1988;30(1):3-24. https://doi.org/10.1017/ S0010417500015024

42. Khare RS. The Hindu hearth and home. New Delhi: Vikas Publishing House: 1976.

43. Srinivas MN, Rao MSA, Sham AM. A survey of research in sociology and social anthropology Vol 3. New Delhi: Popular Prakashan; 1972.

44. Gore MS. Third survey of research in sociology and social anthropology. New Delhi: ICSSR Manak Publications; 2000

45. Soppitt CA. A Short Account of the Kachcha Naga (Empêo) Tribe in the North Cachar Hills: With an outline grammar, vocabulary, and illustrative sentences. Shillong: Assam Secrtt Press; 1885.

46. Stewart R. Notes on Northern Cachar. J Asiat Soc. 1855;24(7):582-701.

47. Bower UG. Cycle-Migration of the Zemi Nagas, North Cachar Hills, Assam. Man India. 1946;26:50-2.

48. Hodson TC. The Naga Tribes of Manipur. London: Macmillan; 1911.

49. Bourdieu P. Distinction: a social critique of the judgment of taste. Cambridge: Harvard University Press; 1984.

50. Kahn M. Always hungry, never greedy: food and the expression of gender in a Melanesian society. Long Grove: Waveland Press; 1993.

51. Weismantel MJ. Food, gender, and poverty in the Ecuadorian Andes. Philadelphia: University of Pennsylvania Press; 1989.

52. Counihan C. Introduction — food and gender: identity and power. In: Counihan CM, Kaplan SL, editors. Food and gender: identity and power. Amsterdam: Harwood Academic; 1998. p. 8-18.

53. Van Esterik P. Right to food; right to feed; right to be fed. The intersection of women's rights and the right to food. Agric Hum Values. 1999;16(2):22532. https://doi.org/10.1023/A:1007524722792.

54. Pollock NJ. These roots remain: food habits in islands of the central and eastern Pacific since western contact. Laie: Institute of Polynesian Studies; 1992.

55. Ansen W. Gender identity and the rituals of food in a Jordanian community Food Foodways. 1997;7(2):87-117. https://doi.org/10.1080/07409710.1997. 9962056.

56. Flynn KC. Food, gender, and survival among street adults in Mwanza. Tanzania. Food Foodways. 1999;8(3):175-201. https://doi.org/10.1080/ 07409710.1999 .9962087$.

57. Douglas M. Constructive drinking. In: Douglas M, editor. Constructive drinking: perspectives on drink from anthropology. London: Routledge; 1987. p. 3-15.

58. Sutton DE. Remembrance of repasts: an anthropology of food and memory. Oxford: Berg Publishers; 2001.

59. Simoons FJ. Eat not this flesh: food Avoidances from prehistory to the present. Madison: University of Wisconsin Press; 1994.

60. Vialles N, Noilie V. Animal to edible. Paris: Cambridge University Press; 1994.

61. Lindenbaum S. Rice and wheat: the meaning of food in Bangladesh. In: Khare RS, Rao MSA, editors. Food, society, and culture: aspects in South Asian food systems. Durham: Carolina Academic Press; 1986. p. 253-76.

\section{Publisher's Note}

Springer Nature remains neutral with regard to jurisdictional claims in published maps and institutional affiliations. 